\title{
Ohmic heating polyphenolic extracts from vine pruning residue with enhanced biological activity
}

\author{
Meirielly S. Jesus ${ }^{a}$, Lina F. Ballesteros ${ }^{a}$, Ricardo N. Pereira ${ }^{a}$, Zlatina Genisheva ${ }^{a}{ }^{\text {, }}$, \\ Ana C. Carvalho ${ }^{\mathrm{b}, \mathrm{c}}$, Cristina Pereira-Wilson ${ }^{\mathrm{a}, \mathrm{b}}$, José A Teixeira ${ }^{\mathrm{a}}$, Lucília Domingues ${ }^{\mathrm{a}}$ \\ ${ }^{a}$ CEB - Centre of Biological Engineering, University of Minho, 4710-057 Braga, Portugal \\ ${ }^{\mathrm{b}}$ Department of Biology, University of Minho, Braga, Portugal \\ ${ }^{\mathrm{c}}$ Centre for the Research and Technology of Agro-Environmental and Biological Sciences, University of Tras-os-Montes e Alto Douro, Vila Real, Portugal
}

\section{A R T I C L E I N F O}

\section{Chemical compounds:}

ABTS (PubChem CID: 90658258)

Apigenin (PubChem CID: 5280443)

Catechin (PubChem CID: 73160)

DMSO (PubChem CID: 329830510)

DPPH (PubChem CID: 2735032)

Ellagic acid (PubChem CID: 5281855)

Ferulic acid (PubChem CID: 445858)

Gallic acid (PubChem CID: 370)

HidroxiTyrosol (PubChem CID: 329815209)

Hesperidin (PubChem CID: 24895680)

Iron(II) sulfate (PubChem CID: 24393)

Iron(III) Cloride (PubChem CID: 24380)

MTT (PubChem CID: 24896603)

o-cumaric acid (PubChem CID: 637540)

Quercetin (PubChem CID: 5280343)

Resveratrol (PubChem CID: 445154)

Rosmarinic acid (PubChem CID: 5281792)

Taxifolin (PubChem CID: 329768169)

Trolox (PubChem CID: 40634)

Tyrosol (PubChem CID: 329768224)

TPTZ (PubChem CID: 77258)

Vanillic acid (PubChem CID: 8468)

Keywords:

Vine pruning residue

Ohmic extraction

Phenolic compounds

Anticancer activity

Antimicrobial activity

Antioxidant activity

\begin{abstract}
A B S T R A C T
Vine Pruning residue was submitted to conventional heating and ohmic heating $(\mathrm{OH})$ for the extraction of bioactive compounds and analyzed for total phenolic content (TPC), polyphenolic profile, antioxidant activity, antimicrobial activity and anticancer activity. The $\mathrm{OH}$ extracts were obtained using Low electric field (496.0 V/ $\mathrm{cm})$ or Intermediate electric field - IEF $(840.0 \mathrm{~V} / \mathrm{cm})$. The tests were performed using $45 \%(\mathrm{v} / \mathrm{v})$ ethanol-water extraction solution at $80{ }^{\circ} \mathrm{C}$ at different extraction times (20-90 $\left.\mathrm{min}\right)$. The extract that stood out among the others concerning anticancer potential was the one obtained by $\mathrm{OH}$ when used, IEF, where the TPC was significantly higher than in the other extracts which correlated with higher antioxidant, antimicrobial and antiproliferative activity on different tumor cell lines (HepG2, MDA-MB-231, MCF-7 and Caco2). Vine pruning OH extracts obtained using green solvents by an eco-friendly procedure were revealed as a source of compounds with relevant antioxidant and anticancer activity.
\end{abstract}

\section{Introduction}

Vine Pruning residue (VPR) is a lignocellulosic material widely generated in the Mediterranean region by the wine industries, as a consequence of the great wine market. Conversely, this waste represents a pollution hazard if discharged into the environment. On the

\footnotetext{
* Corresponding author.

E-mail addresses: merielly_@hotmail.com (M.S. Jesus), linafernanda37@gmail.com (L.F. Ballesteros), rpereira@deb.uminho.pt (R.N. Pereira), zgenisheva@gmail.com (Z. Genisheva), anacpcarvalho@gmail.com (A.C. Carvalho), cpereira.bio.uminho@gmail.com (C. Pereira-Wilson), jateixeira@deb.uminho.pt (J.A. Teixeira), luciliad@deb.uminho.pt (L. Domingues).
} 


Nomenclature
$\begin{array}{ll}\text { Abbreviations } \\ \text { ABTS } & \text { 2,2'-azino-bis-3-ethylbenzthiazoline-6-sulphonic acid } \\ \text { ATCC } & \text { American Type Culture Collection } \\ C H & \text { Conventional Heating } \\ C F U & \text { colony forming unit } \\ D M E M & \text { Dulbecco's Modified Eagle's Medium } \\ D M S O & \text { dimethyl sulfoxide } \\ D P P H & 2,2 \text {-diphenyl-1-picryl-hydrazyl-hydrate } \\ E C C A & \text { European Collection of Authenticated Cell Cultures } \\ F B S & \text { Fetal Serum Bovine } \\ F E(I I) & \text { ferrous equivalents } \\ G A E & \text { Gallic Acid Equivalent } \\ H z & \text { hertz } \\ k H z & \text { kilohertz } \\ I E F & \text { Intermediate electric field } \\ L E F & \text { Low Electric Field } \\ M E M & \text { Minimum Essential Medium } \\ m h a & \text { Million Hectares }\end{array}$

$\begin{array}{ll}m h l & \text { Million hectoliters } \\ M H z & \text { Megahertz } \\ M T T & \text { Methylthiazolyldiphenyl-tetrazolium bromide } \\ \text { OH } & \text { Ohmic heating } \\ \text { RPMI-1640 Medium Roswell Park Memorial Institute-1640 } \\ R T & \text { Room temperature } \\ \text { UHPLC } & \text { Ultra-high-performance liquid chromatography } \\ V & \text { Volts } \\ V P R & \text { Vine Pruning Residue }\end{array}$

Parameters and constants

$\begin{array}{ll}A_{O} & \text { Absorbance of control (DPPH or ABTS) } \\ A_{1} & \text { Absorbance of extracts } \\ I a & \text { Inhibition activity (\%) } \\ I C_{50} & \begin{array}{l}\text { Concentration of sample or standard that can inhibit } 50 \% \\ \text { of DPPH, ABTS }(\mathrm{mg} / \mathrm{mL}) \text { or } 50 \% \text { of cell viability }(\mu \mathrm{g} / \mathrm{mL})\end{array} \\ C V & \begin{array}{l}\text { cell viability }(\%) \\ V_{1}\end{array} \\ V_{2} & \text { cell viability of control sample } \\ \end{array}$

other hand, VPR is economically underutilized, however, it has attracted enormous attention due to its interesting properties and its possible use as a raw material to obtain added-value compounds. In fact, this by-product can be considered a rich source of energy and bioactive compounds, and the recovery of these compounds from VPR could avoid the possible economic and environmental concerns. In this context, some authors have proposed different alternative applications for the valorization of this residue. Thus, VPR can be used to produce biochar (Azuara, Sáiz, Manso, García-Ramos, \& Manyà, 2017), enological additives (Cebrián-Tarancón et al., 2019), bioethanol (Jesus, Romaní, Genisheva, Teixeira, \& Domingues, 2017), bioactive compounds (Rajha et al., 2018), or foliar fertilizers (Sánchez-Gómez, GardeCerdán, et al., 2016), reducing sugars, and soluble lignin (Rajha et al., 2018) as well as others. In spite of these applications, VPR is still underutilized as a valuable material for industrial processes.

Nowadays, studies for reusing wine production residues as potential sources of phenolic compounds have gained great interest since these compounds present multiple biological effects, including antioxidant (Jesus et al., 2019), anti-mutagenic, anti-inflammatory, antimicrobial and anti-carcinogenic properties (Tartaglione et al., 2018), which provide enormous benefits for human health. According to some authors, extracts of different residues from the wine industry, such as leaves, seeds and, vine pruning may be toxic to different human cancer cells. As a result, leaf extracts were tested for human colon cancer cells and A549 lung cancer cells (Abed, Harb, Khasib, \& Saad, 2015; Ramadan, Abou-Taleb, Galal, \& Abdel-Hamid, 2017). The extracts from the VPR was subjected to the extraction, purification and isolation of oligostilbenoids in order to be tested against normal MRC-5 lung fibroblasts, AGS gastric adenocarcinoma cells, SK-MES-1 lung stem cells and bladder carcinoma cells J82 (Sáez et al., 2018).

Factors such as the origin and composition of the raw material, the type of solvent used and its concentration, the solid/solvent ratio, time of contact, temperature, and extraction methodology, significantly influence the efficiency of the process extraction of bioactive compounds (Jesus et al., 2019). Previous works regarding the extraction of phenolic compounds using VPR as a raw material have tested different solvents including methanol (Ju et al., 2016), butanone and acetone (Alexandru et al., 2014). However, these solvents are mostly toxic to humans. Taking into account the potential application of these extracts in human health sector, researchers are looking for technologies able to use green solvents such as water (Gullón et al., 2017; Jesus et al., 2017; Moreira et al., 2018; Sánchez-Gómez, Zalacain, Alonso, \& Salinas, 2016), ethanol (Alexandru et al., 2014) or ethanol-water mixtures (Alexandru et al., 2014; Jesus et al., 2019; Moreira et al., 2018) in order to ensure the attainment of phenolic compounds suitable for the food, pharmaceutical and cosmetic industries.

Thus, alternative eco-friendly methodologies including alkaline hydrolysis treatments (Max, Salgado, Cortés, \& Domínguez, 2010; Rajha, Boussetta, Louka, Maroun, \& Vorobiev, 2015b), ultrasound-assisted extraction (Alexandru et al., 2014; Delgado-Torre, Ferreiro-Vera, Priego-Capote, Pérez-Juan, \& Luque De Castro, 2012; Farhadi, Esmaeilzadeh, Hatami, Forough, \& Molaie, 2016), hydrothermal treatment at high temperatures (Gullón et al., 2017; Jesus et al., 2017), solid-liquid dynamic extraction (Delgado-Torre et al., 2012; LuqueRodríguez, Pérez-Juan, \& de Castro, 2006; Sánchez-Gómez, Zalacain, Alonso, \& Salinas, 2014), subcritical water extraction (Gabaston et al., 2018; Moreira et al., 2018), as well as high-voltage electrical discharge (Rajha, Boussetta, Louka, Maroun, \& Vorobiev, 2015a), have been applied. However, the current methods used for the extraction of bioactive compounds present limitations due to the long extraction times and high process temperatures, which can cause oxidation and denaturation of the phenolic compounds since they are relatively unstable, leading to low extraction percentages. Therefore, it is necessary to study novel extraction methodologies capable of extracting high concentrations of bioactive compounds using less aggressive conditions and environmentally friendly and sustainable solvents. One of the eco-friendly trends in the techniques of extracting polyphenolic compounds is the use of emerging technologies such as ohmic heating $(\mathrm{OH})$ to reduce the damaging effects of conventional thermal processes.

$\mathrm{OH}$ is one of the emerging high potential technologies where the passage of alternating electric current is used to generate heat internally (Pereira et al., 2018). This process was used in different studies for the production, pasteurization and shelf-life enhancement of beverages, flours and sausages (Cappato et al., 2018; Ferreira et al., 2019; Inmanee, Kamonpatana, \& Pirak, 2019; Makroo, Prabhakar, Rastogi, \& Srivastava, 2019; Ramírez-Jiménez et al., 2019). Additionally, this technique involves less aggressive heat treatments than others usually used because of its ability to heat materials evenly and rapidly, preventing thus, the denaturization of thermosensitive substances including the phenolic compounds (Khan et al., 2018; Ramírez-Jiménez et al., 2019). Some authors have reported that the use of OH causes destruction of the cell membrane making it permeable and thus, raising the release of phenolic compounds from plant tissues (Kulshrestha \& Sastry, 2010; Lebovka, Shynkaryk, \& Vorobiev, 2007). The 
permeabilization increases with the rise of the intensity and temperature of the electric field (El Darra, Grimi, Vorobiev, Louka, \& Maroun, 2013). Previous studies showed that the use of ethanol/water blends in pulsed ohmic heating accelerates the extraction kinetics of this type of compounds from grape marc (El Darra et al., 2013).

Currently, studies of bioactive compound extractions performed from VPR have been concentrated on the qualitative/quantitative evaluation of polyphenols and on their antioxidant activity and antimicrobial capacity onto bacteria and yeasts. However, to the best of our knowledge, there are no studies that use the sustainable and environmentally friendly ohmic heating to recovery bioactive compounds from VPR. In addition, there is no study in the literature that reports the antimicrobial inhibition of VPR extracts onto filamentous fungi, as well as the anti-carcinogenic activity when used a VPR integral extract in order to evaluate the synergistic effects of the set of bioactive compounds present in that extract. Therefore, the aim of this study was to investigate the levels of polyphenolic compounds and their profile, as well as the functional properties, including antioxidant and antimicrobial capacities, and cytotoxic activity in human tumor cell lines, in produced extracts from VPR by using the emerging $\mathrm{OH}$ extraction technique at different intensities: Intermediate electric field (IEF) and Low electric field (LEF).

\section{Materials and methods}

\subsection{Raw material and analysis of the chemical composition}

Vine pruning residue (VPR) from $V$. vinifera variety Loureiro were collected randomly from the Portuguese region of Minho (Amares, Braga-PT) in January of 2015. Samples were dried at room temperature, milled to pass an $8 \mathrm{~mm}$ mesh, homogenized in a single batch and stored at room temperature into a dark and dry place until use. The VPR used in this work was previously studied and characterized (Jesus et al., 2019; Jesus et al., 2017) and presents the following chemical composition: $32.9 \pm 0.6$ of cellulose (as glucan); $14.9 \pm 0.2$ of xylan; $0.4 \pm 0.01$ of arabinan; $3.9 \pm 0.5$ of acetyl groups; $29.5 \pm 1.2$ of Klason lignin; $13.7 \pm 1.0$ of extractives in water; $2.9 \pm 0.9$ of extractives in ethanol and $3.3 \pm 0.5$ of ashes, expressed in $\mathrm{g}$ per $100 \mathrm{~g}$ VPR on oven-dry basis \pm standard deviation based in three replicate determinations.

\subsection{Extraction process}

The extraction of phenolic compounds from VPR was performed by conventional heating $(\mathrm{CH})$ and $\mathrm{OH}$ techniques. The extraction parameters defined in this study were based on previous results (Jesus et al., 2019). Briefly, the extractions were carried out in a glass cylindrical reactor of $30 \mathrm{~cm}$ total length and $2.3 \mathrm{~cm}$ of internal diameter containing two electrodes of stainless steel insulated with polytetrafluoroethylene, which kept constant at $7 \mathrm{~cm}$ of distance. Voltages were controlled using a function generator (Agilent $33.220 \mathrm{~A}$, Bayan Lepas, Malaysia, $1 \mathrm{~Hz}-$ $25 \mathrm{MHz}$, and 1-10 V) with a sinusoidal wave at a $25 \mathrm{kHz}$ frequency, connected to an amplifier (Peavey CS3000, Meridian, MS, USA, $0.3-170 \mathrm{~V}$ ). The electric fields ranged from 400 to $1600 \mathrm{~V} / \mathrm{cm}$, and the temperature was monitored by a k-type thermocouple (precision temperature $\pm 1{ }^{\circ} \mathrm{C}$, Omega, 709, USA) placed in the geometric center of the sample volume and connected to a data logger software (National Instruments, USB-9161, USA), according to previous reports (Pereira et al., 2010; Rodrigues, Vicente, Petersen, \& Pereira, 2019).

For the extractions, $1 \mathrm{~g}$ of VPR was suspended in $40 \mathrm{~mL}$ of a hydroalcoholic solution at $45 \%(\mathrm{v} / \mathrm{v})$, put inside the reactor and maintained to a constant agitation with a magnetic stirrer. $\mathrm{NaCl}$ was used to adjust the electrical conductivity of the solution $(2.3 \mathrm{mS} / \mathrm{cm})$ in order to ensure a homogeneous current flow. The power was controlled to reach a temperature of $80^{\circ} \mathrm{C}$, and the extraction time ranged from 20 to 90 min. Extraction of polyphenolic compounds was performed for samples subjected at four different treatments, all of them carried out into the glass cylindrical reactor. Thus, an IEF $(840.0 \mathrm{~V} / \mathrm{cm})$ and LEF $(496.0 \mathrm{~V} / \mathrm{cm})$ treatment (using an extraction time of $60 \mathrm{~min}$ ) were applied. For the IEF only the electrodes were used to achieve $80{ }^{\circ} \mathrm{C}$, while for LEF, an additional thermo-stabilized water bath circulating in the reactor jacket was used to reach the temperature. On the other hand, $\mathrm{CH}$ extraction treatment was made using a circulating thermostabilized water bath in the reactor jacket, and finally, an extraction treatment at room temperature, used as a control, was performed (RT). All experiments were made in triplicate.

At the end of each treatment, the obtained extracts were immediately cooled down in an ice bath in order to stop the reaction, and then, filtered with a paper filter of cellulose. The ethanol was evaporated on an orbital shaker at $40{ }^{\circ} \mathrm{C}$ and $150 \mathrm{rpm}$, and the extracts lyophilized and stored for further analysis.

\subsection{Analytical methodology}

\subsubsection{Total phenolic compounds analysis}

The total phenolic compounds (TPC) of the VPR extracts were determined by using the Folin-Ciocalteu reagent, adapted to $96-$ well microplate, as described by Ballesteros, Cerqueira, Teixeira, and Mussatto (2015). In detail, to a sample of $10 \mu \mathrm{L}$ were added $60 \mu \mathrm{L}$ of sodium carbonate solution $(7.5 \%, \mathrm{w} / \mathrm{v}), 15 \mu \mathrm{L}$ of Folin-Ciocalteu reagent (Sigma-Aldrich Co., St. Louis, MO, USA) and $200 \mu \mathrm{L}$ distilled water. Finally, the plate was heated at $60{ }^{\circ} \mathrm{C}$ for $6 \mathrm{~min}$, and the absorbance was measured at $700 \mathrm{~nm}$ against a blank sample using UV-Vis (Synergy HTBIOTEK).

The total phenolic content was calculated as equivalents of gallic acid from a standard curve $(Y=0.0007 x+0.0671, r=0.99433)$. The results were expressed in grams of equivalent gallic acid per $100 \mathrm{~g}$ dry matter (g GAE/100 g VPR).

\subsubsection{UHPLC analyses}

In addition, phenolic compounds were also identified and quantified by Shimatzu Nexpera X2 UHPLC chromatograph equipped with Diode Array Detector (Shimadzu, SPD-M20A). The separation was performed on a reversed-phase Acquity UPLC BEH C18 column $\left(2.1 \mathrm{~mm} \times 100 \mathrm{~mm}, 1.7 \mu \mathrm{m}\right.$ particle size; from Waters) at $40{ }^{\circ} \mathrm{C}$. The flow rate was $0.4 \mathrm{~mL} / \mathrm{min}$. The solvents used were water/formic acid $(0.1 \%)$ as solvent $\mathrm{A}$ and acetonitrile as solvent $\mathrm{B}$, the elution gradient used was according Jesus et al. (2019). The phenolic compounds were identified by comparing their UV/Vis spectra and retention times, at the most suitable wave-length for each compound, with that of corresponding standards (Jesus et al., 2019).

\subsubsection{Antioxidant activity analysis}

The effect of $\mathrm{OH}$ and $\mathrm{CH}$ techniques on the antioxidant activity of the extracted bioactive compounds was evaluated by using different antioxidant assays as described below.

Ferric reducing antioxidant power (FRAP) assay, was carried out according the methodology described by (Ballesteros, Cerqueira, Teixeira, \& Mussatto, 2015; Meneses, Martins, Teixeira, \& Mussatto, 2013). Thus, FRAP reagent was prepared from a $0.3 \mathrm{M}$ acetate buffer solution, $10 \mathrm{mM}$ 2,4,6-Tris (2-pyridyl)-s-triazine (TPTZ) and a $40 \mathrm{mM}$ aqueous ferric chloride solution in a ratio of 10:1:1 (v/v/v). For the analysis, $10 \mu \mathrm{L}$ of the filtered samples were added to $290 \mu \mathrm{L}$ of the FRAP reagent into a 96-well microplate and then, the samples were incubated at $37{ }^{\circ} \mathrm{C}$ for $15 \mathrm{~min}$. The absorbance was recorded at $593 \mathrm{~nm}$ (Synergy HT-BIOTEK). The $\mathrm{FeSO}_{4}$ (10 to $275 \mathrm{mg} / \mathrm{L}$ ) was used as a standard and water used as a blank. The results were expressed in grams of ferrous equivalent per $100 \mathrm{~g}$ of VPR extract ( $\mathrm{g} \mathrm{FE} / 100 \mathrm{~g}$ VPR).

DPPH radical scavenging assay was carried out preparing a solution of 2,2-diphenyl-1-picrylhydrazine (DPPH) radical in methanol $\left(6 \times 10^{-5} \mathrm{M}\right.$ to an absorbance of 0.700 at $\left.515 \mathrm{~nm}\right)$ as described by (Meneses et al., 2013; Sánchez-Gómez, Zalacain, Pardo, Alonso, \& 
Salinas, 2017). Briefly, aliquots of $10 \mu \mathrm{L}$ of each sample were added to $290 \mu \mathrm{L}$ of DPPH solution into a 96-well microplate, and the samples were kept in dark for $1 \mathrm{~h}$ at room temperature, and then, measured at $515 \mathrm{~nm}$ using detector UV-Vis (Synergy HT-BIOTEK). Negative and positive controls were made with methanol, and the standard curve was linear between 48 and $719 \mu \mathrm{M}$ Trolox.

On the other hand, radical cation decolorization (ABTS) assay was determined according to Ballesteros and co-workers (2015). ABTS radical cation was prepared by mixing $7.4 \mathrm{mM}$ 2.2-azino-bis-(3-ethylbenzthiazoline-6-sulfonic acid) diammonium salt (ABTS) dissolved in ethanol with potassium persulfate $(2.6 \mathrm{mM})$ in a ratio of $1: 1(\mathrm{v} / \mathrm{v})$. The mixture was kept for $16 \mathrm{~h}$ at room temperature in the dark. After $16 \mathrm{~h}$, $1 \mathrm{~mL}$ of ABTS radical cation solution was added to approximately $50 \mathrm{~mL}$ of solution absolute ethanol and then adjusted to an absorbance of 0.700 at $734 \mathrm{~nm}$ using detector UV-Vis (Synergy HT-BIOTEK). In a 96-well microplate, aliquots of $10 \mu \mathrm{L}$ of each sample were added to $200 \mu \mathrm{L}$ of the ABTS radical cation solution and the samples were kept in dark for 6 min at $30{ }^{\circ} \mathrm{C}$.

The inhibition activity (\%) of DPPH and ABTS were calculated following the equation:

\%Inhibition activity $=\frac{A_{0}-A_{1}}{A_{1}} \times 100$

where $A_{0}$ is the absorbance of the negative control and $A_{1}$ is the absorbance of the extracts. The sample concentration for the inhibition concentration at $50 \%\left(\mathrm{IC}_{50}\right)$ for both methodologies was calculated by interpolation. The antioxidant activity was expressed as the amount of antioxidant able to reduce the initial concentration of DPPH and ABTS by $50 \%$. The $\mathrm{IC}_{50}$ values were expressed as $\mathrm{g}$ of Trolox equivalent per $100 \mathrm{~g}$ of dry weight material ( $\mathrm{g}$ TE/100 $\mathrm{g}$ VPR).

\subsubsection{Antimicrobial activity analysis}

2.3.4.1. Microbial strains. Antimicrobial evaluation was performed against five food pathogenic fungi that drastically influence the quality and safety of postharvest fruits including Alternaria sp. (MUM 02.42), Cladosporium cladosporioides (MUM 97.06), Phoma violacea (MUM 97.08), Penicillium italicum (MUM 02.25) and Penicillium expansum (MUM 02.14), being obtained from the collection of the Mycology Laboratory of the Minho University (MUM), Portugal. All strains were cultured into potato dextrose agar (PDA) and incubated at $25 \pm 2{ }^{\circ} \mathrm{C}$ during 15 days before the antimicrobial test.

2.3.4.2. Micro-dilution methodology for filamentous fungi. The determination of the optimal inhibitory concentration of the obtained extracts from VPR against microbial strains was performed using the micro-dilution methodology for filamentous fungi described by the Clinical and Laboratory Standards Institute (CLSI, 2002). Thus, the fungi cell number was adjusted to approximately $10^{6} \mathrm{CFU}$ (colony forming unit) $/ \mathrm{mL}$ ( 0.5 on the McFarland scale). Additionally, a lyophilized fraction $(2 \mathrm{mg} / \mathrm{mL})$ of the VPR extracts obtained from each treatment were serially two-fold diluted in the synthetic culture medium RPMI 1640 (with glutamine and without sodium bicarbonate buffered with bicarbonate 3-( $N$-morpholino) propanesulfonic acid MOPS), in order to obtain final concentrations from 1000 to $1.95 \mu \mathrm{g} /$ $\mathrm{mL}$. Experiments were carried out in a sterile 96-well microplate, in which $100 \mu \mathrm{L}$ of inoculum suspension was added to $100 \mu \mathrm{L}$ sample. The microplate was incubated at $25 \pm 2{ }^{\circ} \mathrm{C}$ for $96 \mathrm{~h}$ and the absorbance was measured at $530 \mathrm{~nm}$ using a spectrophotometric microplate reader (Sunrise Tecan, Grödig, Austria). The behavior of the samples was evaluated against growth and sterility controls, which consisted in using $100 \mu \mathrm{L}$ of medium RPMI 1640 plus $100 \mu \mathrm{L}$ of inoculum suspension as a microbial growth control (negative control) and $200 \mu \mathrm{L}$ of medium RPMI 1640 as a sterility control (positive control). Moreover, fluconazole solutions (concentrations from 0.19 to $100 \mu \mathrm{g}$ / $\mathrm{mL}$ ) were used as standard controls. All the treatments were analyzed against the 5 fungi, and the concentrations of each treatment capable of inhibiting growth when compared with the negative control were considered as the optimal conditions.

\subsubsection{Anticancer activity analysis}

2.3.5.1. Cell culture and experimental conditions. Caco2 human colon carcinoma cells, MDA-MB-231 and MCF-7 human breast cancer cells were kindly provided by Dr. Raquel Seruca (Ipatimup, University of Porto, Portugal). HepG2 human hepatocellular carcinoma cells (HB8065) and CCD841 CoN normal human colonic cells (CRL-1790) were purchased from American Type Culture Collection (ATCC, Rockville, MD). Cells were maintained at $37^{\circ} \mathrm{C}$ in a humidified $5 \% \mathrm{CO}_{2} / 95 \%$ air (v/v) atmosphere in the appropriate culture medium. Caco-2 cells were maintained in DMEM supplemented with 10 mM HEPES, 10\% FBS, 1\% antibiotic/antimycotic solution, and $1 \%$ non-essential amino acids solution. On the other hand, MDA-MB-231cells were cultivated in DMEM with $10 \mathrm{mM}$ HEPES, $1.5 \mathrm{~g} / \mathrm{L}$ sodium bicarbonate, 10\% FBS, and $1 \%$ antibiotic/antimycotic solution, while MCF-7 in RPMI-1640 supplemented with $10 \mathrm{mM}$ HEPES, $1 \mathrm{mM}$ sodium pyruvate, $1.5 \mathrm{~g} / \mathrm{L}$ sodium bicarbonate, $10 \% \mathrm{FBS}$, and $1 \%$ antibiotic/antimycotic solution. Finally, HepG2 and CCD841 CoN cells were maintained in MEM supplemented with $10 \mathrm{mM}$ HEPES, $1 \mathrm{mM}$ sodium pyruvate, $1.5 \mathrm{~g} / \mathrm{L}$ sodium bicarbonate, $10 \% \mathrm{FBS}$, and $1 \%$ antibiotic/antimycotic solution.

For cell experiments, Caco2 cells were seeded at 50,000 cells $/ \mathrm{mL}$, MDA-MB-231 and MCF-7 at 75,000 cells/mL, HepG2 at 200,000 cells/ $\mathrm{mL}$, and CCD841 CoN at 75,000 cells/mL, 24 h before incubation with the different extracts. Stock solutions of lyophilized extracts were prepared in dimethyl sulfoxide (DMSO) and kept in aliquots at $-20{ }^{\circ} \mathrm{C}$. Extracts were then added to the culture medium just before incubation, keeping the DMSO concentration not higher than 0.5\% (v/v). Controls contained only DMSO.

2.3.5.2. Assessment of anticancer effect on cancer cell lines. The effect of varying concentrations of the tested extracts obtained from the distinct extraction procedures (in 24 and $48 \mathrm{~h}$ incubations) on cell proliferation was evaluated by the methylthiazolyldiphenyl-tetrazolium bromide (MTT) reduction assay as previously described (Lima, Pereira-Wilson, \& Rattan, 2011). Briefly, $2 \mathrm{~h}$ before the end of the treatment period, the cells were incubated with MTT to a final concentration of $0.5 \mathrm{mg} / \mathrm{mL}$. After removing the medium, the formazan crystals formed by the cell's capacity to reduce MTT were dissolved with a DMSO: ethanol solution $50: 50(\mathrm{v} / \mathrm{v})$, and measured at an absorbance of $570 \mathrm{~nm}$. The results were expressed as a percentage relative to the control (cells without any test extract). The extract concentration that inhibited cell growth by $50 \%\left(\mathrm{IC}_{50}\right.$ ) relative to control was calculated using GraphPad Prism 7.0 software (San Diego, CA, USA).

\subsection{Statistical analysis}

All experiments were conducted in triplicate. Statistical significances were assessed by two-way ANOVA and Tukey post hoc test (95\% confidence interval), using Statistica software (version 10) and GraphPad Prism 7.0. Differences between groups were considered to be significant when $p \leq 0.05$.

\section{Results and discussion}

\subsection{Determination of ohmic heating extraction conditions: Preliminary assays}

The extraction time can significantly influence the concentration of TPC, impacting on the antioxidant activity of the extracts (Jesus et al., 2019), besides reducing the energy consumption and cost of the extraction process. Therefore, it is important to evaluate the extraction time to optimize the recovery of the bioactive compounds. For defining the extraction process conditions, preliminary tests were performed in order to evaluate the optimum extraction time (20-90 $\mathrm{min}$ ) for $\mathrm{OH}$ 
treatments in comparison to the tests carried out by the $\mathrm{CH}$ and RT methods, being the last one used as a control. The temperature $\left(80{ }^{\circ} \mathrm{C}\right)$ and the liquid/solid ratio (40:1 mL/g of VPR) were defined according to results obtained in previous $\mathrm{CH}$ extractions (Jesus et al., 2019). The extraction time efficiency was evaluated in terms of the recovered TPC and the antioxidant activity evaluated by different methods, including FRAP, DPPH and ABTS (Fig. 1). For evaluating the treatments, the TPC concentration and the antioxidant activity of the samples obtained by $\mathrm{OH}$ and $\mathrm{CH}$ were compared with the control extraction (RT) method, inferred by two-way ANOVA.

The results showed no significant differences $(p>0.05)$ for the polyphenol content in the extracts obtained by $\mathrm{CH}$ and $\mathrm{OH}(3.2 \pm 0.1$ and $3.1 \pm 0.2 \mathrm{~g} \mathrm{GAE} / 100 \mathrm{~g}$, respectively, at $60 \mathrm{~min}$ ) for all evaluated times, correlating with the values previously reported by other authors (Çetin, Altinöz, Tarçan, \& Baydar, 2011; Jesus et al., 2019; Moreira et al., 2018). However, there were significant differences between treatments with respect to the antioxidant activity where $\mathrm{OH}$ treatment presented the best FRAP value ( $3.1 \pm 0.3 \mathrm{~g} \mathrm{FE} / 100 \mathrm{~g}$ ), and also the highest values when DPPH $(3.2 \pm 0.4 \mathrm{~g} \mathrm{TE} / 100 \mathrm{~g})$ and ABTS $(1.50 \pm 0.2 \mathrm{~g} \mathrm{TE} / 100 \mathrm{~g})$ assays were determined. In general, it was possible to observe significant differences $(p<0.05)$ between the extraction treatments and the time of extraction in the $\mathrm{OH}$ treatment, with the better result obtained with $60 \mathrm{~min}$ of extraction. Therefore, $60 \mathrm{~min}$ may be considered an adequate time to be used in all the extraction processes, which is an advantage, since the use of the extraction times shorter result in important economic viewpoints.

\subsection{Experimental TPC and antioxidant extraction}

Bioactive compounds from VPR, were extracted with a $40 \%$ hydroalcohol solution, at $80{ }^{\circ} \mathrm{C}$, for $60 \mathrm{~min}$. The VPR were subjected to three methods of extracting, including $\mathrm{CH}, \mathrm{OH}$ with two different electric field intensities (LEF- Low Electric Field and IEF-Intermediate Electric Field), and a treatment at RT, which was used as controls Table 1. The total content of phenolic compounds extracted by $\mathrm{OH}$ using IEF was $23 \%$ higher than that obtained in previous works from high electrical voltage (2.0 g GAE/100 g VPR) (Rajha et al., 2018). In addition, significant $(p<0.05)$ variations of TPC in the extracts obtained through the different extraction methods were observed, being IEF and LEF the extract with the highest TPC values $(3.4 \pm 0.1$ and $3.1 \pm 0.2 \mathrm{~g} \mathrm{GAE} / 100 \mathrm{~g}$ VPR, respectively). The extract obtained through RT treatment (1.2 $\pm 0.1 \mathrm{~g} \mathrm{GAE} / 100 \mathrm{~g}$ VPR), as expected, exhibited the lowest TPC values, which is in agreement with other authors, who observed a marked reduction of TPC in extracts obtained at low temperatures (Jesus et al., 2019; Sánchez-Gómez, SánchezVioque, et al., 2017). The temperature directly influences the TPC concentration, since mild treatments are not able to solubilize the phenolic compounds present in the lignicellulosic materials. The extracts produced by the IEF treatments had statistically higher concentrations $(p>0.05)$ compared to the RT, CH and LEF treatments indicating that the electric field strength could positively affect the final TPC concentration (Rajha et al., 2015b). Althought there are no significant difference between the extracts produced with $\mathrm{CH}$ ans LEF treatments. a

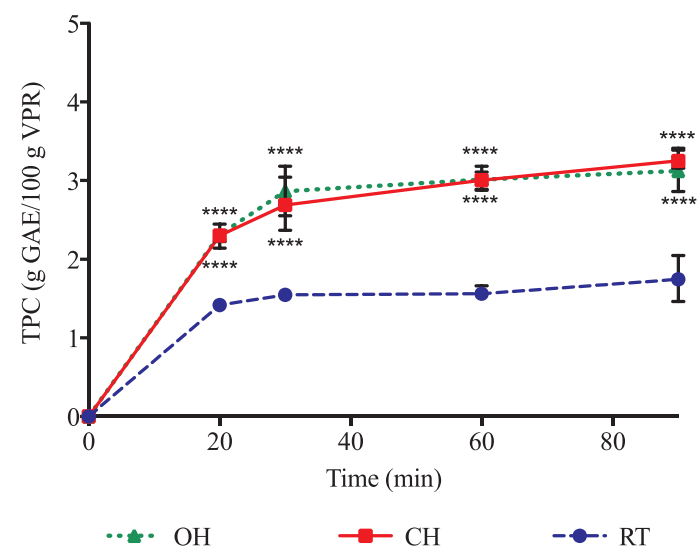

c

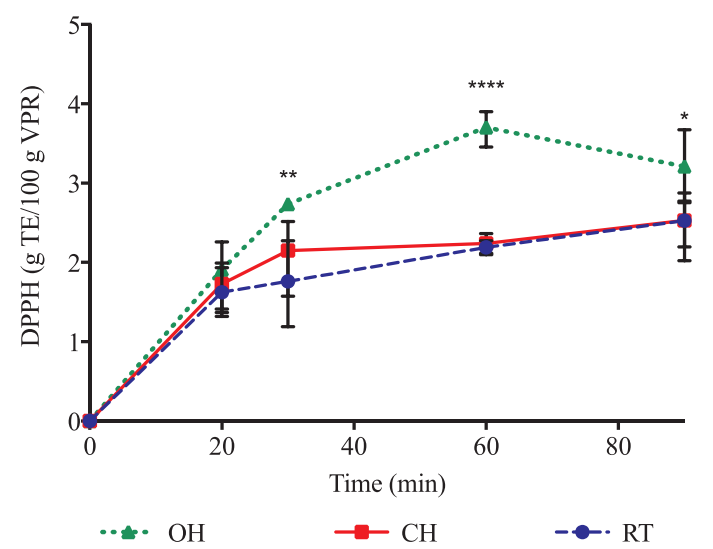

b

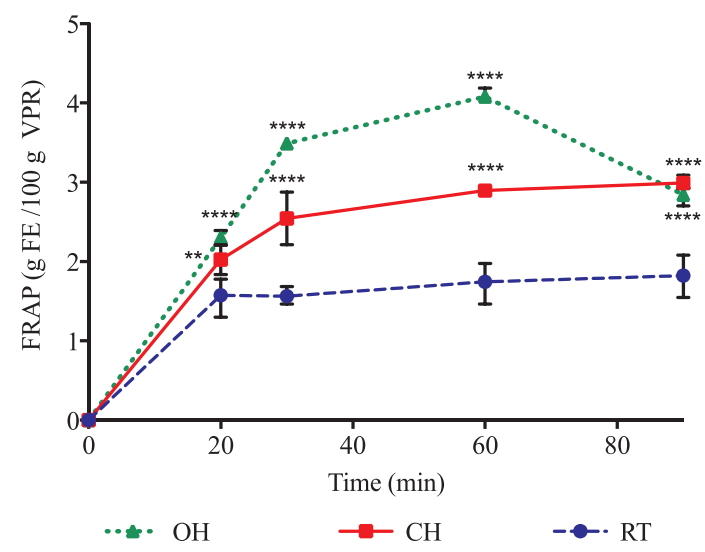

d

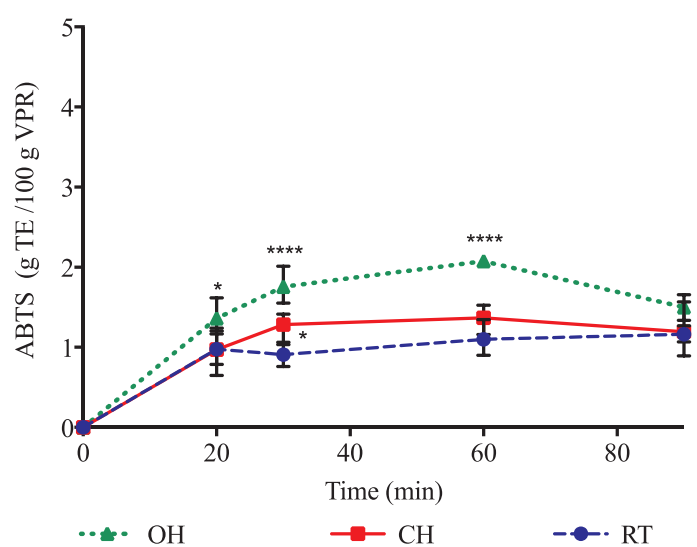

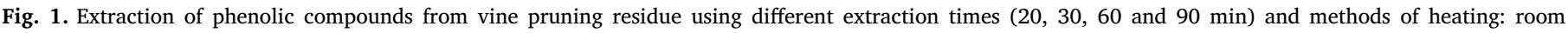

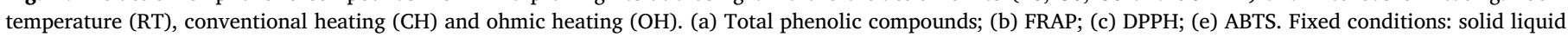

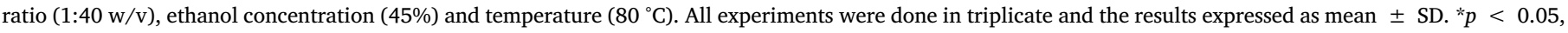
${ }^{* *} p<0.01, * * * p<0.001$, **** $p<0.0001$. 
Table 1

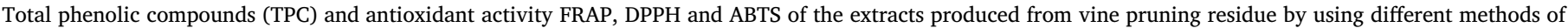

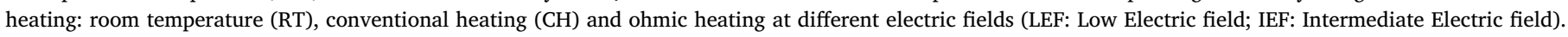

\begin{tabular}{|c|c|c|c|c|c|c|}
\hline \multirow[t]{2}{*}{ Runs } & \multirow{2}{*}{$\begin{array}{l}\text { TPC } \\
\text { g GAE/100 g VPR }\end{array}$} & \multirow{2}{*}{$\begin{array}{l}\text { FRAP } \\
\text { g FE/100 g VPR }\end{array}$} & \multicolumn{2}{|l|}{ DPPH } & \multicolumn{2}{|l|}{ ABTS } \\
\hline & & & $\mathrm{g}$ TE/100 g VPR & $\mathrm{IC}_{50}$ & $\mathrm{~g}$ TE/100 g VPR & $\mathrm{IC}_{50}$ \\
\hline IEF & $3.4 \pm 0.1^{\mathrm{c}}$ & $4.6 \pm 0.2^{\mathrm{c}}$ & $4.1 \pm 0.1^{\mathrm{d}}$ & $0.76^{\mathrm{a}}$ & $3.1 \pm 0.1^{\mathrm{c}}$ & $0.34^{\mathrm{a}}$ \\
\hline LEF & $3.1 \pm 0.2^{\mathrm{b}}$ & $4.1 \pm 0.3^{\mathrm{b}}$ & $3.2 \pm 0.1^{\mathrm{c}}$ & $0.90^{\mathrm{b}}$ & $1.9 \pm 0.2^{\mathrm{b}}$ & $0.44^{\mathrm{b}}$ \\
\hline $\mathrm{CH}$ & $3.0 \pm 0.2^{\mathrm{b}}$ & $3.7 \pm 0.1^{\mathrm{d}}$ & $2.7 \pm 0.2^{\mathrm{b}}$ & $0.95^{\mathrm{b}}$ & $1.9 \pm 0.1^{\mathrm{b}}$ & $0.40^{\mathrm{b}}$ \\
\hline RT & $1.2 \pm 0.1^{\mathrm{a}}$ & $1.7 \pm 0.2^{\mathrm{a}}$ & $2.2 \pm 0.1^{\mathrm{a}}$ & $1.25^{\mathrm{c}}$ & $1.01 \pm 0.1^{\mathrm{a}}$ & $0.94^{c}$ \\
\hline
\end{tabular}

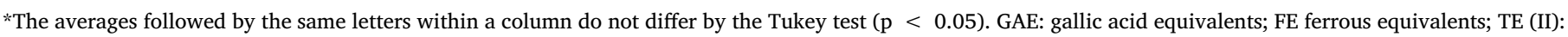
Trolox equivalents. Antiradical activity is expressed as a mean $\left(\mathrm{n}=3\right.$ ) of $\mathrm{IC}_{50}$ values ( $\mathrm{g}$ of extract/L of solution).

The experimental results showed that the highest antioxidant activities evaluated by FRAP ( $4.6 \pm 0.2 \mathrm{~g} \mathrm{FE} / 100 \mathrm{~g})$, DPPH $(4.0 \pm 0.1 \mathrm{~g}$ $\mathrm{TE} / 100 \mathrm{~g})$ and ABTS $(3.1 \pm 0.1 \mathrm{~g}$ TE/100 g) assays were achieved when the ohmic IEF heating was used. The LEF treatment presented higher antioxidant activities for FRAP (4.1 $\pm 0.3 \mathrm{~g} \mathrm{FE} / 100 \mathrm{~g})$ and DPPH (3.2 $\pm 0.1 \mathrm{~g}$ TE/100 g) assays compared with the obtained values when $\mathrm{CH}$ and RT methods were carried out. However, the ABTS values presented no significant differences $(p>0.05)(1.9 \pm 0.1 \mathrm{~g}$ TE/100 g) between both, LEF and CH treatments. Previous works have shown that there is a great influence of the applied electric field on the antioxidant activity values when FRAP and DPPH assay were determined, showing better results with respect to other extraction methodologies (Cappato et al., 2018; Loypimai, Moonggarm, \& Chottanom, 2009). When the comparison based on the extraction method is conducted, (Table 1), it becomes evident that RT and $\mathrm{CH}$ were the worst methods for obtaining extracts with relevant antioxidant activity. The increase of the intensity of the electric discharges in the IEF treatment raises the TPC and the antioxidant activity in the VPR extracts, probably due to the microscopic damages induced by shock waves of pressure that lead to the deterioration of the structural components of the residue, facilitating the rupture of the tissues by cavitation bubbles (Boussetta et al., 2012). These results highlight the significant effects of using IEF to extract antioxidant phenolic compounds in relation to other extraction methods.

Additionally, half of the maximal inhibitory concentration ( $\left.\mathrm{IC}_{50}\right)$ was also calculated by the DPPH and ABTS assays. The highest value was obtained in the extracts obtained by the $\mathrm{CH}$ and RT treatments, which means that the electric fields have influenced positively the extraction of bioactive compounds in VPR.

\subsection{Chemical composition of VPR extracts}

The samples extracted using $\mathrm{OH}$ at two different intensities (LEF and IEF), $\mathrm{CH}$ and RT techniques were analyzed by UHPLC (Ultra high-performance liquid chromatography) and the identification and quantification of the phenolic compounds present in the extracts were carried out. The compounds identified in VPR extracts (results expressed in $\mathrm{mg} / 100 \mathrm{~g}$ of VPR) are listed in Table 2.

Twelve different types of polyphenolic compounds including phenolic acid, flavonoids, phenylethanoids and stilbenes, were identified and quantified using their corresponding standards. The LEF and IEF extracts showed the highest concentrations of flavonoids. However, apigenin and hesperidin flavonoids, were more abundant in IEF treatment ( 287.2 and $180.3 \mathrm{mg} / 100 \mathrm{~g}$ VPR, respectively) than LEF, and were not identified in the extracts obtained by $\mathrm{CH}$ and RT treatments. The concentration of apigenin in LEF was higher than that previously described (Jesus et al., 2019), which was $207.9 \mathrm{mg}$ of apigenin per $100 \mathrm{~g}$ of VPR when a conventional liquid-solid method using a $45 \%$ hydroalcoholic solution and $120 \mathrm{~min}$ of extraction was applied. Other authors employed a conventional heating method to extract the same compound from grape pomace, using an $80 \%$ hydroalcoholic solution and acetone as extraction solvents, obtaining extracts with $9.1 \mathrm{mg}$ apigenin /100 g of grape pomace (Pintać et al., 2018; Dutra et al., 2018). Hesperidin was also found analyzed the extraction of phenolic compounds from conventional grape juice $\left(4.04 \mathrm{mg} / \mathrm{L}^{-1}\right)$, conventional wines $\left(4.9 \mathrm{mg} / \mathrm{L}^{-1}\right)$ and organic wines $\left(4.3 \mathrm{mg} / \mathrm{L}^{-1}\right)$. On the other hand, quercetin was present in all extracts, IEF, LEF and CH (287.2, 286.8 and $281.6 \mathrm{mg} / 100 \mathrm{~g} \mathrm{VPR}$, respectively) with significantly higher concentrations $(p<0.05)$ than in RT $(132.8 \mathrm{mg} / 100 \mathrm{~g}$ VPR). These values were higher than those obtained in previous works when used $\mathrm{CH}$ extraction (27.7 mg/100 g VPR) (Jesus et al., 2019) and microwave extraction ( $82.1 \mathrm{mg} / 100 \mathrm{~g}$ VPR) (Moreira et al., 2018). The identification of this compound in the VPR extracts is relevant, since quercetin is the main flavonol present in vine leaves of white and red grape varieties, representing more than $70 \%$ of total flavonols (Flamini, Mattivi, De Rosso, Arapitsas, \& Bavaresco, 2013).

Single phenols were identified as hydroxytyrosol and tyrosol. Hydroxytyrosol was not identified in the RT extracts and did not present statistically significant $(p>0.05)$ differences in the concentrations found in the extracts obtained by CH, LEF and IEF (149.6, 151.6, and $152.4 \mathrm{mg} / 100 \mathrm{~g} \mathrm{VPR}$, respectively). IEF extract presented the highest tyrosol concentration (142.3 mg/100 g VPR), followed by LEF and $\mathrm{CH}$ (139.8 and $137.1 \mathrm{mg} / 100 \mathrm{~g}$ VPR, respectively), which showed no statistically significant differences $(p>0.05)$ and RT extract (64.2 mg/100 g VPR). Hydroxytyrosol and tyrosol were also identified in samples of commercial white Greek wines of Vitis vinifera L. cv. Malagusia (Tourtoglou, Nenadis, \& Paraskevopoulou, 2014).

Although stilbenes are extensively explored in VPR studies, in this study trans-resveratrol was the unique compound identified in the extracts. The highest trans-resveratrol concentration was obtained in the LEF treatment (137.3 mg/100 g VPR), where it was twice as high as the

Table 2

Polyphenolic composition of the VPR extracts (Expressed as mg/100 g VPR) obtained by different methods of heating: room temperature (RT), conventional heating $(\mathrm{CH})$ and ohmic heating at different electric fields (LEF: Low Electric field; IEF: Intermediate Electric field).

\begin{tabular}{lllll}
\hline Polyphenols (mg/100 g VPR) & IEF & LEF & CH & RT \\
\hline Phenolics acid & & & & \\
Gallic acid & $2.9^{\mathrm{b}}$ & $3.5^{\mathrm{a}}$ & $\mathrm{ND}$ & $\mathrm{ND}$ \\
o-Cumaric acid & $15.8^{\mathrm{b}}$ & $26.5^{\mathrm{c}}$ & $14.2^{\mathrm{b}}$ & $6.6^{\mathrm{a}}$ \\
Ferulic acid & $46.6^{\mathrm{a}}$ & $46.1^{\mathrm{a}}$ & $\mathrm{ND}$ & $\mathrm{ND}$ \\
Ellagic acid & $222.9^{\mathrm{b}}$ & $77.7^{\mathrm{a}}$ & $\mathrm{ND}$ & $\mathrm{ND}$ \\
Vanillic acid & $68.4^{\mathrm{bc}}$ & $70.3^{\mathrm{c}}$ & $67.2^{\mathrm{b}}$ & $31.2^{\mathrm{a}}$ \\
Flavonoids & & & & \\
Hesperidin & $180.3^{\mathrm{b}}$ & $149.0^{\mathrm{a}}$ & $\mathrm{ND}$ & $\mathrm{ND}$ \\
Apigenin & $384.2^{\mathrm{b}}$ & $157.5^{\mathrm{a}}$ & $\mathrm{ND}$ & $\mathrm{ND}$ \\
Quercetin & $287.2^{\mathrm{bc}}$ & $286.8^{\mathrm{bc}}$ & $281.6^{\mathrm{b}}$ & $132.8^{\mathrm{a}}$ \\
Taxifolin & $23.7^{\mathrm{c}}$ & $21.8^{\mathrm{bc}}$ & $19.8^{\mathrm{a}}$ & $\mathrm{ND}$ \\
Simple phenols & & & & \\
HidroxiTyrosol & $152.4^{\mathrm{c}}$ & $151.6^{\mathrm{bc}}$ & $149.6^{\mathrm{bc}}$ & $\mathrm{ND}$ \\
$\begin{array}{l}\text { Tyrosol } \\
\text { Stilbenes }\end{array}$ & $142.3^{\mathrm{c}}$ & $139.8^{\mathrm{b}}$ & $137.1^{\mathrm{b}}$ & $64.2^{\mathrm{a}}$ \\
trans-resveratrol & & & & \\
\hline
\end{tabular}

*Where The averages followed by the same letters within a file do not differ by the Tukey test $(p<0.05)$. ND: not detected. 
IEF extract value (65.4 mg/100 $\mathrm{g}$ VPR). These values are in agreement with those obtained by other authors (Moreira et al., 2018), who evaluated the extraction of trans-resveratrol ( $136 \mathrm{mg} / 100 \mathrm{~g}$ VPR) from two varieties of Portuguese grapes by using microwave extraction.

As it is well known, residues of the wine industry have been extensively studied for the extraction of bioactive compounds. However, the different cultivars, parts of the plant, geographical location, climatic conditions and storage time can influence on the properties and chemical composition of the recovered compounds (Cebrián-Tarancón et al., 2019). The content in flavonols in VPR is the one that varies most according to the grape varieties (Cebrián, Sánchez-Gómez, Salinas, Alonso, \& Zalacain, 2017). The main phenolic compounds found in this work were apigenin, quercetin, ellagic acid and hesperidin. According to Delgado-Torre and co-workers, catechin was the main phenolic compound isolated in VPR extract (Delgado-Torre et al., 2012;), while in other studies, (E)-resveratrol followed by (E)- $\varepsilon$-viniferine were also identified as the main phenolic compounds in VPR extracts (Gabaston et al., 2018). Other authors found in VPR, after toasting treatment, high concentrations of proanthocyanidins (Cebrián-Tarancón et al., 2018). On the other hand, studies based on the polyphenolic composition extracted from VPR by using heating by electric fields are scarce, and most of them use pulsed electro technologies and water as the extraction solvent followed by other pre-treatments. In addition, these studies have described the presence of kaempferol, epicatechin, resveratrol, hydrodobenzoic acid, p-coumaric acid and ferulic acid (Rajha, Boussetta, Louka, Maroun, \& Vorobiev, 2014; Rajha et al., 2015a, 2018). In other varieties of vine-shoots the majority of the flavonols of the present study were not detected, instead the flavanols content (catechin and epicatechin) was the most important (Cebrián et al., 2017). It was proven that the content of flavanols varied significantly according to the time elapsed since pruning (Cebrián-Tarancón et al., 2018; Cebrián et al., 2017).

\subsection{Antimicrobial activity of VPR extracts}

The VPR extracts obtained in this study through LEF, IEF, CH and RT treatments were screened for antimicrobial activity against five fungi using a micro-dilution methodology. All fungi were evaluated as a function of the incubation time (assessing the growth rate at 24, 48, 72 and $96 \mathrm{~h}$ ) at $25 \pm 2{ }^{\circ} \mathrm{C}$. Thus, different concentrations of each extract $(1000,500,250,125,62.5,31.3,15.6,7.8,3.9,1.95 \mu \mathrm{g} / \mathrm{mL})$ were tested against Alternaria sp., Cladosporium cladosporioides, Phoma violacea, Penicillium italicum and Penicillium expansum in order to observe the fungal growth and determine the optimal inhibitory extract concentrations for each treatment. The main results are summarized in
Table 3, where are presented the two best concentrations found of each extract (LEF, IEF, CH and RT) to inhibit the growth of the evaluated fungi. In a general way, all the extracts exhibited antifungal activity against the studied fungi, showing greater activity after $96 \mathrm{~h}$ of exposure at the different extract concentrations. Antifungal activity varied according to the concentrations and extracts, although none of the concentrations used presented $100 \%$ inhibition. Some authors suggest plant extracts as potential natural antifungal agents because of the need for low dosages to achieve antimicrobial bioactivity and reducing negative sensory impact on food (Kumar, Kujur, Singh, \& Prakash, 2019).

The highest antimicrobial inhibition was obtained when the maximum extract concentration $(1000 \mu \mathrm{g} / \mathrm{mL})$ was tested after $96 \mathrm{~h}$ of incubation. In addition, IEF, LEF and $\mathrm{CH}$ extracts expressed much more significant inhibitory effects against $P$. italicum, $P$. expansum and $C$. cladosporioides when the same concentration $(1000 \mu \mathrm{g} / \mathrm{mL})$ was used, in contrast to RT extract that only presented a high percent inhibition against $P$. italicum. In general, VPR extracts showed a growth inhibition from 18.1 to $68.2 \%$ (Table 3 ) when the maximum concentration was applied. On the other hand, the minimum inhibitory concentration for $\mathrm{CH}$ and RT extracts was $15.6 \mu \mathrm{g} / \mathrm{mL}$, showing inhibition percentages between 12.3 and 38.5 and $18.1-37.3 \%$, respectively. The results showed that the IEF extract presented a significant inhibitory power against C. cladosporioides (38.4\%) and Phoma violacea (24.5\%) when $3.9 \mu \mathrm{g} / \mathrm{mL}$ extract was used, as well as against $P$. italicum (30.5\%) and P. expansum (21.3\%)when $7.8 \mu \mathrm{g} / \mathrm{mL}$ extract was tested. As regards the LEF extract, the minimum inhibitory concentration was $3.9 \mu \mathrm{g} / \mathrm{mL}$ for P. expansum, which was able to inhibit $13.1 \%$, whereas for P. italicum and Phoma violacea the concentration $7.8 \mu \mathrm{g} / \mathrm{mL}$ was able to inhibit $38.8 \%$ and $14.2 \%$ of the fungal growth, respectively. Finally, Alternaria sp. and C. cladosporioides showed a percent growth inhibition of $25.8 \%$ and $27.1 \%$, respectively, to $15.6 \mu \mathrm{g} / \mathrm{mL}$ of LEF extract. The LEF and IEF extracts showed minimal inhibitory concentrations that expressed stronger antifungal activities for Alternaria sp., C. cladosporioides, $P$. violacea, $P$. italicum and $P$. expansum. These results are related to the phenolic profile and antioxidant activity previously provided.

Some authors claim that the antifungal effects of plant extracts and essential oils rich in bioactive compounds such as flavonoids are related to the disruption of the fungal cell endomembrane system (plasma membrane and mitochondria) and mitochondrial dysfunction, inducing metabolic stagnation (Hu, Zhang, Kong, Zhao, \& Yang, 2017; Yang et al., 2017). Inhibition of fungal growth and germination can be explained by the presence of flavonoids such as quercetin, hesperidin and apigenin, and phenolic acid such as ellagic acid, which have the capacity to reduce microbial growth, making a preferential alternative to synthetic antimicrobial agents, as these are environment friendly and

Table 3

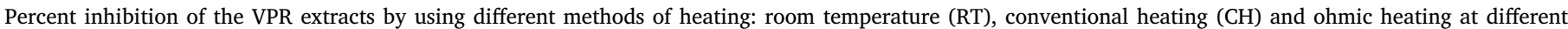
electric fields (LEF: Low Electric field; IEF: Intermediate Electric field) against the growth of different fungi calculated after 96 h of exposure.

\begin{tabular}{|c|c|c|c|c|c|c|c|c|}
\hline \multirow{2}{*}{$\begin{array}{l}\text { Extraction technique } \\
\text { Fungi }\end{array}$} & \multicolumn{2}{|l|}{ IEF } & \multicolumn{2}{|l|}{ LEF } & \multicolumn{2}{|l|}{$\mathrm{CH}$} & \multicolumn{2}{|l|}{ RT } \\
\hline & $\begin{array}{l}\text { Extracts } \\
\text { concentration }(\mu \mathrm{g} / \\
\mathrm{mL})\end{array}$ & Inhibition (\%) & $\begin{array}{l}\text { Extracts } \\
\text { concentration ( } \mu \mathrm{g} / \\
\mathrm{mL})\end{array}$ & Inhibition (\%) & $\begin{array}{l}\text { Extracts } \\
\text { concentration }(\mu \mathrm{g} / \\
\mathrm{mL})\end{array}$ & Inhibition (\%) & $\begin{array}{l}\text { Extracts } \\
\text { concentration }(\mu \mathrm{g} / \\
\mathrm{mL})\end{array}$ & Inhibition (\%) \\
\hline \multirow[t]{2}{*}{ Penicillium italicum } & 7.8 & $30.5 \pm 1.9$ & 7.8 & $38.8 \pm 3.4$ & 15.6 & $38.5 \pm 8.1$ & 15.6 & $37.3 \pm 2.5$ \\
\hline & 1000 & $68.2 \pm 1.2^{\mathrm{a}}$ & 1000 & $66.5 \pm 1.4^{\mathrm{a}}$ & 1000 & $67.8 \pm 4.5^{\mathrm{a}}$ & 1000 & $64.3 \pm 2.9^{\mathrm{a}}$ \\
\hline \multirow[t]{2}{*}{ Penicillium expansum } & 7.8 & $21.3 \pm 9.6$ & 3.9 & $13.1 \pm 5.9$ & 15.6 & $24.6 \pm 3.4$ & 15.6 & $18.1 \pm 6.1$ \\
\hline & 1000 & $53.3 \pm 10.3^{\mathrm{a}}$ & 1000 & $54.5 \pm 13.7^{\mathrm{a}}$ & 1000 & $34.7 \pm 3.4^{\mathrm{b}}$ & 1000 & $25.0 \pm 8.3^{c}$ \\
\hline \multirow[t]{2}{*}{ Alternaria sp. } & 15.6 & $20.9 \pm 2.1$ & 15.6 & $25.8 \pm 5.4$ & 15.6 & $24.9 \pm 11.7$ & 15.6 & $27.8 \pm 6.0$ \\
\hline & 1000 & $40 \pm 5.2^{\mathrm{d}}$ & 1000 & $45.4 \pm 7.5^{\mathrm{c}}$ & 1000 & $32.1 \pm 1.6^{\mathrm{a}}$ & 1000 & $35.1 \pm 1.2^{\mathrm{b}}$ \\
\hline \multirow[t]{2}{*}{ Phoma violacea } & 3.9 & $24.5 \pm 2.1$ & 7.8 & $14.2 \pm 3.1$ & 15.6 & $12.3 \pm 6.4$ & 15.6 & $21.4 \pm 11.5$ \\
\hline & 1000 & $41 \pm 5.9^{c}$ & 1000 & $33.9 \pm 4.5^{\mathrm{a}}$ & 1000 & $31.6 \pm 2.1^{\mathrm{a}}$ & 1000 & $28.5 \pm 5.8^{\mathrm{b}}$ \\
\hline \multirow{3}{*}{$\begin{array}{l}\text { Cladosporium } \\
\text { Cladosporioides }\end{array}$} & 3.9 & $38.4 \pm 3.3$ & 15.6 & $27.1 \pm 2.7$ & 15.6 & $30.3 \pm 17.9$ & 15.6 & $26.0 \pm 10.4$ \\
\hline & & & & & & & & \\
\hline & 1000 & $62.4 \pm 7.9^{\mathrm{a}}$ & 1000 & $59.9 \pm 2.7^{\mathrm{a}}$ & 1000 & $43.8 \pm 5.4^{\mathrm{b}}$ & 1000 & $18.1 \pm 9.2^{\mathrm{c}}$ \\
\hline
\end{tabular}

*The statistic was carried out only for the concentration of $1000 \mu \mathrm{g} / \mathrm{mL}$. The averages followed by the same letters within a line do not differ by the Tukey test $(p<0.05)$. 
easy to use (Kumar et al., 2019; Yang et al., 2017).

\subsection{Anticancer activity of VPR extracts}

The anticancer potential of VPR extracts was evaluated by their capacity to decrease the cell proliferation of four different cancer cell lines (MDA-MB-231, MCF-7, HepG2, and Caco2) and a non-carcinogenic cell line (CCD $841 \mathrm{CoN}$ ) being assessed by the MTT assay. As shown in Table 4, all VPR extracts inhibited cell growth in a concentration- and time-dependent manner in all cell lines tested. In recent years, several studies have attributed to flavonoids the selective reduction of cell viability of cancer cells (Mahmoudi et al., 2019; Tavsan \& Kayali, 2019; Zhu, Wang, Jia, \& Xie, 2019). These results can be attributed, among other compounds, to the abundant presence of quercetin in all extracts, which is considered to have anticancer potential due to its ability to induce apoptosis and inhibit the progression of numerous human cancer cell lines (Rauf et al., 2018). The IEF extract showed the most potent activity against MDA-MB-231, MCF-7, HepG2, Caco2, and CCD $841 \mathrm{CoN}$ cells with $\mathrm{IC}_{50}$ values after $48 \mathrm{~h}$ of exposure of 62.8, 54.7, 89.7, 49.7, 71.0 $\mu \mathrm{g} / \mathrm{mL}$, respectively (Table 4). The distinct polyphenolic composition of the VPR extracts may explain the different growth inhibitory capacity between the VPR extracts. Taking into account the chemical characterization of the VPR extracts, apigenin, ellagic acid, hesperidin and quercetin are more abundant in the IEF extract than in the other extracts. Some authors recognize apigenin as a potential inhibitor of viability of human lung carcinoma cells (A549), while not showing significant side effects in healthy human umbilical vein endothelial cells (HUVEC) (Mahmoudi et al., 2019). Apigenin is considered an efficient inhibitor of the expression of nuclear factor E2related factor 2 important contributor to chemoresistance in cancer therapy (Gao, Ke, Shi, Sun, \& Chen, 2013; Paredes-Gonzalez et al., 2015). Over the years, studies with hesperidin have shown potent antiinflammatory effects, anticancer and chemopreventive antioxidants (Kamaraj et al., 2019; Roohbakhsh, Parhiz, Soltani, Rezaee, \& Iranshahi, 2015). In earlier studies hesperidin significantly inhibited the cell viability of human lung cancer A549 cells (Kamaraj et al., 2019), Caco2 cells (El-Readi, Hamdan, Farrag, El-Shazly, \& Wink, 2010) and MCF-7 breast cancer cells (Febriansah, Dyaningtyas, Sarmoko, Meiyanto, \& Nugroho, 2014), these works suggest hesperidin as a new agent in carcinoma therapy. Other authors show that keratin enhances anticancer and proapoptotic effects in colon CO115 and HCT1 cell lines and has also been shown to act on KRAS and PI3K (Xavier et al., 2009; Xavier, Lima, Rohde, \& Pereira-Wilson, 2011). Previous publications showed that ellagic acid isolated from Phyllanthus emblica L. exert a dose-dependent anticancer activity against MCF-7 cells in a concentration range between 5 and $50 \mu \mathrm{g} / \mathrm{mL}$ (Luo et al., 2011).

The cancer cell lines MDA-MB-231, MCF-7, HepG2, and Caco2 were more sensitive to VPR extracts than CCD 841 CoN non-carcinogenic cells under the same treatment conditions. A chemopreventive agent should have strong inhibitory effect on cell proliferation and carcinogenic pathways of cancer cells however, minimal effect on healthy cells. For the treatment of cancer, the natural therapies by plant extracts may reduce the side effects and toxic effects of therapies (Liu, Wang, Tang, Bowater, \& Bao, 2019; Ramadan et al., 2017). However, HepG2 cancer cells were less sensitive to VPR extracts than CCD 841 CoN cells. This may be explained by the fact that HepG2 cells retain many of the specialized function of normal hepatocytes (Liu et al., 2019).

These results demonstrated that the IEF extract inhibits cell growth and its effect may be related to its chemical composition. Since, the inhibition of cell growth evaluated by the MTT assay could be attributed to decreased cell proliferation, induction of cell death or both, it would be interesting in the future to evaluate the effects of the VPR extracts on cell cycle and death. The results of this study represent preliminary results that will be beneficial for the evaluation of the bioactive potential of extracts of VPR and the development of novel chemotherapeutic agents.

\section{Conclusions}

In this study, the extraction of polyphenolic compounds from Vine Pruning Residue (VPR) was evaluated through different electric field intensities (LEF electric field and intermediate electric field - IEF) using the environmentally friendly $\mathrm{OH}$ extraction procedure and compared to two conventional extractions (Room Temperature- RT and Conventional Heating-CH). Overall, VPR was validated as a good source for phenolic compounds that can be exploited as ingredients for application on the food, pharmaceutical or cosmetic industries. The extracts obtained by the environmentally friendly $\mathrm{OH}$ technique presented better results in comparison to the other treatments most probably due to the rupture of the cells by the electric current passage. These results suggest that $\mathrm{OH}$ in IEF is an effective technique for extracting phenolic compounds from VPR. In addition, the IEF extract, which used higher electrical intensity, showed greater enrichment in the phenolic compounds, antioxidant activity, antimicrobial activity, and cancer cell growth inhibitory activity. Besides its enhanced biological activity, these extracts have additional advantages for application in food, pharmaceutical or cosmetic industries in comparison with other extraction techniques as no toxic solvents have to be removed.

\section{CRediT authorship contribution statement}

Meirielly S. Jesus: Formal analysis, Investigation. Lina F. Ballesteros: Conceptualization, Methodology. Ricardo N. Pereira: Conceptualization, Methodology. Zlatina Genisheva: Conceptualization, Methodology, Validation. Ana S. Carvalho: Investigation. Cristina Pereira-Wilson: Conceptualization, Methodology, Resources. José A Teixeira: Supervision, Funding acquisition, Resources. Lucília Domingues: Supervision, Funding

Table 4

$\mathrm{IC}_{50}$ values $(\mu \mathrm{g} / \mathrm{mL})$ of VPR extracts obtained by different methods of heating: room temperature (RT), conventional heating $(\mathrm{CH})$ and ohmic heating at different electric fields (LEF: Low Electric field; IEF: Intermediate Electric field) against different cancer cell lines (MDA-MB-231- human breast, MCF-7- human breast, HepG2human hepatocellular, and Caco2- human colon) and a non-carcinogenic cell line (CCD $841 \mathrm{CoN}$ - human colon), calculated after $24 \mathrm{~h}$ and $48 \mathrm{~h}$ of exposure.

\begin{tabular}{|c|c|c|c|c|c|c|c|c|}
\hline \multirow[t]{3}{*}{ Cell lines } & \multicolumn{8}{|l|}{$\mathrm{IC}_{50}(\mu \mathrm{g} / \mathrm{mL})$} \\
\hline & IEF & & LEF & & $\mathrm{CH}$ & & RT & \\
\hline & $24 \mathrm{~h}$ & $48 \mathrm{~h}$ & $24 \mathrm{~h}$ & $48 \mathrm{~h}$ & $24 \mathrm{~h}$ & $48 \mathrm{~h}$ & $24 \mathrm{~h}$ & $48 \mathrm{~h}$ \\
\hline MDA-MB-231 & $91.7 \pm 12.7^{\mathrm{ab}}$ & $62.8 \pm 6.5^{\mathrm{a}}$ & $116.1 \pm 6.5^{\mathrm{a}}$ & $74.2 \pm 5.6^{\mathrm{a}}$ & $119.9 \pm 14.8^{\mathrm{a}}$ & $79.1 \pm 8.2^{\mathrm{a}}$ & $137 \pm 4.8^{\mathrm{ab}}$ & $86.97 \pm 14.2^{\mathrm{a}}$ \\
\hline MCF-7 & $154.6 \pm 21.7^{\mathrm{bc}}$ & $54.7 \pm 5.3^{\mathrm{a}}$ & $167.2 \pm 76.5^{\mathrm{bc}}$ & $62.7 \pm 4.9^{\mathrm{a}}$ & $186 \pm 14.6^{\mathrm{b}}$ & $65.7 \pm 6.1^{\mathrm{a}}$ & $222.9 \pm 64.6^{\mathrm{cd}}$ & $70.8 \pm 10.1^{\mathrm{a}}$ \\
\hline HepG2 & $134.3 \pm 27.7^{\mathrm{ab}}$ & $89.7 \pm 13.7^{\mathrm{ab}}$ & $193.4 \pm 51.1^{\mathrm{a}}$ & $117.7 \pm 15.3^{\mathrm{a}}$ & $198.8 \pm 29.9^{\mathrm{a}}$ & $117.2 \pm 16.1^{\mathrm{a}}$ & $216.2 \pm 28.7^{\mathrm{bc}}$ & $122.7 \pm 25.0^{\mathrm{a}}$ \\
\hline Caco2 & $76.2 \pm 4.0^{\mathrm{ab}}$ & $49.7 \pm 6.0^{\mathrm{a}}$ & $104.3 \pm 12.6^{\mathrm{a}}$ & $62.7 \pm 3.7^{\mathrm{a}}$ & $105.2 \pm 8.5^{\mathrm{b}}$ & $65.9 \pm 6.3^{\mathrm{a}}$ & $115.2 \pm 9.5^{\mathrm{b}}$ & $83.8 \pm 7.4^{\mathrm{ab}}$ \\
\hline CCD $841 \mathrm{CoN}$ & $283.4 \pm 5.6^{c}$ & $71.0 \pm 0.3^{\mathrm{a}}$ & $337.9 \pm 5.4^{\mathrm{b}}$ & $78.1 \pm 2.1^{\mathrm{a}}$ & $435.6 \pm 8.1^{b}$ & $81.6 \pm 1.1^{\mathrm{a}}$ & $430.9 \pm 8.8^{b}$ & $99.0 \pm 2.1^{\mathrm{a}}$ \\
\hline
\end{tabular}

*Where Values are expressed as mean \pm SEM of three independent experiments. The averages followed by the same letters within a line do not differ by the Tukey test $(p<0.05)$. 
acquisition.

\section{Declaration of Competing Interest}

The authors declare that they have no known competing financial interests or personal relationships that could have appeared to influence the work reported in this paper.

\section{Acknowledgments}

This work has been carried out at the Biomass and Bioenergy Research Infrastructure (BBRI)- LISBOA-01-0145-FEDER-022059, supported by Operational Programme for Competitiveness and Internationalization (PORTUGAL2020), by Lisbon Portugal Regional Operational Programme (Lisboa 2020) and by North Portugal Regional Operational Programme (Norte 2020) under the Portugal 2020 Partnership Agreement, through the European Regional Development Fund (ERDF) and has been supported by the Portuguese Foundation for Science and Technology (FCT) under the scope of the strategic funding of UIDB/04469/2020 and BioTecNorte operation (NORTE-01-0145FEDER-000004) funded by the European Regional Development Fund under the scope of Norte2020 - Programa Operacional Regional do Norte. Meirielly S. Jesus thanks her fellowship supported by the International Cooperation Program $\mathrm{CNPq} / \mathrm{CSF}$ at the University of Minho financed by CNPq-Brazilian Federal Agency. Zlatina Genisheva thanks to FCT for the financial support (ref. SFRH/BPD/108868/2015). Ana Cristina Carvalho was supported by the INTERACT project "Integrated Research Environment, Agro-Chain and Technology", no. NORTE-01-0145-FEDER-000017, in its line of research entitled ISAC, co-financed by the European Regional Development Fund (ERDF) through NORTE 2020 (North Regional Operational Program 2014/ 2020).

\section{Declaration of interests}

The authors declare that they have no known competing financial interests or personal relationships that could have appeared to influence the work reported in this paper.

\section{References}

Abed, A. H., Harb, J., Khasib, S., \& Saad, B. (2015). In vitro assessment of cytotoxic, antioxidant and antimicrobial activities of leaves from two grape varieties collected from arid and temperate regions in Palestine. QScience Connect, 2015(1), 4. https:// doi.org/10.5339/connect.2015.4.

Alexandru, L., Binello, A., Mantegna, S., Boffa, L., Cravotto, G., Chemat, F., \& Cravotto, G. (2014). Efficient green extraction of polyphenols from post-harvested agro-industry vegetal sources in Piedmont. Comptes Rendus Chimie, 17(3), 212-217. https://doi. org/10.1016/J.CRCI.2013.09.012.

Azuara, M., Sáiz, E., Manso, J. A., García-Ramos, F. J., \& Manyà, J. J. (2017). Study on the effects of using a carbon dioxide atmosphere on the properties of vine shoots-derived biochar. Journal of Analytical and Applied Pyrolysis, 124, 719-725. https://doi.org/10. 1016/j.jaap.2016.11.022.

Ballesteros, L. F., Cerqueira, M. A., Teixeira, J. A., \& Mussatto, S. I. (2015). Characterization of polysaccharides extracted from spent coffee grounds by alkali pretreatment. Retrieved from Carbohydrate Polymers, 127, 347-354. https://www. sciencedirect.com/science/article/pii/S014486171500260X.

Boussetta, N., Vorobiev, E., Reess, T., De Ferron, A., Pecastaing, L., Ruscassié, R., \& Lanoisellé, J.-L. (2012). Scale-up of high voltage electrical discharges for polyphenols extraction from grape pomace: Effect of the dynamic shock waves. Innovative Food Science \& Emerging Technologies, 16, 129-136. https://doi.org/10.1016/j.ifset.2012. 05.004.

Cappato, L. P., Ferreira, M. V. S., Moraes, J., Pires, R. P. S., Rocha, R. S., Silva, R., ... Cruz, A. G. (2018). Whey acerola-flavoured drink submitted Ohmic Heating: Bioactive compounds, antioxidant capacity, thermal behavior, water mobility, fatty acid profile and volatile compounds. Food Chemistry, 263, 81-88. https://doi.org/10.1016/J. FOODCHEM.2018.04.115.

Cebrián-Tarancón, C., Sánchez-Gómez, R., Cabrita, M. J., García, R., Zalacain, A., Alonso, G. L., \& Salinas, M. R. (2019). Winemaking with vine-shoots. Modulating the composition of wines by using their own resources. Food Research International, 121, 117-126. https://doi.org/10.1016/J.FOODRES.2019.03.032.

Cebrián-Tarancón, C., Sánchez-Gómez, R., Gómez-Alonso, S., Hermosín-Gutierrez, I., Mena-Morales, A., García-Romero, E., ... Zalacain, A. (2018). Vine-shoot tannins:
Effect of post-pruning storage and toasting treatment. Journal of Agricultural and Food Chemistry, 66(22), 5556-5562. https://doi.org/10.1021/acs.jafc.8b01540.

Cebrián, C., Sánchez-Gómez, R., Salinas, M. R., Alonso, G. L., \& Zalacain, A. (2017). Effect of post-pruning vine-shoots storage on the evolution of high-value compounds. Industrial Crops and Products, 109, 730-736. https://doi.org/10.1016/j.indcrop.2017. 09.037.

Çetin, E. S., Altinöz, D., Tarçan, E., \& Baydar, N. G. (2011). Chemical composition of grape canes. Industrial Crops and Products, 34(1), 994-998. https://doi.org/10.1016/ j.indcrop.2011.03.004.

CLSI. Reference Method for Broth Dilution Antifungal Susceptibility Testing of Yeasts; Approved Standard-Second Edition, Pub. L. No. 15 (2002). Wayne, Pennsylvania 19087-1898, USA: CLSI document M27-A2. Retrieved from file:///Users/meirielly/ Desktop/M27-A2.pdf.

Delgado-Torre, M. P., Ferreiro-Vera, C., Priego-Capote, F., Pérez-Juan, P. M., \& Luque De Castro, M. D. (2012). Comparison of accelerated methods for the extraction of phenolic compounds from different vine-shoot cultivars. Journal of Agricultural and Food Chemistry, 60(12), 3051-3060. https://doi.org/10.1021/jf205078k.

Dutra, M.da. C. P., Rodrigues, L. L., de Oliveira, D., Pereira, G. E., \& Lima, M.dos. S. (2018). Integrated analyses of phenolic compounds and minerals of Brazilian organic and conventional grape juices and wines: Validation of a method for determination of $\mathrm{Cu}, \mathrm{Fe}$ and Mn. Food Chemistry, 269, 157-165. https://doi.org/10.1016/J. FOODCHEM.2018.07.014.

El-Readi, M. Z., Hamdan, D., Farrag, N., El-Shazly, A., \& Wink, M. (2010). Inhibition of Pglycoprotein activity by limonin and other secondary metabolites from Citrus species in human colon and leukaemia cell lines. European Journal of Pharmacology, 626(2-3), 139-145. https://doi.org/10.1016/J.EJPHAR.2009.09.040.

El Darra, N., Grimi, N., Vorobiev, E., Louka, N., \& Maroun, R. (2013). Extraction of polyphenols from red grape pomace assisted by pulsed ohmic heating. Food and Bioprocess Technology, 6(5), 1281-1289. https://doi.org/10.1007/s11947-0120869-7.

Farhadi, K., Esmaeilzadeh, F., Hatami, M., Forough, M., \& Molaie, R. (2016). Determination of phenolic compounds content and antioxidant activity in skin, pulp, seed, cane and leaf of five native grape cultivars in West Azerbaijan province, Iran. Food Chemistry, 199, 847-855. https://doi.org/10.1016/J.FOODCHEM.2015.12.083.

Febriansah, R., Dyaningtyas, D. P. P., Sarmoko, Nurulita, N. A., Meiyanto, E., \& Nugroho, A. E. (2014). Hesperidin as a preventive resistance agent in MCF-7 breast cancer cells line resistance to doxorubicin. Asian Pacific Journal of Tropical Biomedicine, 4(3), 228-233. https://doi.org/10.1016/S2221-1691(14)60236-7.

Ferreira, M. V. S., Cappato, L. P., Silva, R., Rocha, R. S., Guimarães, J. T., Balthazar, C. F., ... Cruz, A. G. (2019). Ohmic heating for processing of whey-raspberry flavored beverage. Food Chemistry, 297. https://doi.org/10.1016/j.foodchem.2019.125018.

Flamini, R., Mattivi, F., De Rosso, M., Arapitsas, P., \& Bavaresco, L. (2013). Advanced knowledge of three important classes of grape phenolics: Anthocyanins, stilbenes and flavonols. International Journal of Molecular Sciences, 14(10), 19651-19669. https:// doi.org/10.3390/ijms141019651.

Gabaston, J., Leborgne, C., Valls, J., Renouf, E., Richard, T., Waffo-Teguo, P., \& Mérillon, J.-M. (2018). Subcritical water extraction of stilbenes from grapevine by-products: A new green chemistry approach. Industrial Crops and Products, 126, 272-279. https:// doi.org/10.1016/J.INDCROP.2018.10.020.

Gao, A.-M., Ke, Z.-P., Shi, F., Sun, G.-C., \& Chen, H. (2013). Chrysin enhances sensitivity of BEL-7402/ADM cells to doxorubicin by suppressing PI3K/Akt/Nrf2 and ERK/Nrf2 pathway. Chemico-Biological Interactions, 206(1), 100-108. https://doi.org/10.1016/ J.CBI.2013.08.008.

Gullón, B., Eibes, G., Moreira, M. T., Dávila, I., Labidi, J., \& Gullón, P. (2017). Antioxidant and antimicrobial activities of extracts obtained from the refining of autohydrolysis liquors of vine shoots. Industrial Crops and Products, 107, 105-113. https://doi.org/ 10.1016/J.INDCROP.2017.05.034.

Hu, Y., Zhang, J., Kong, W., Zhao, G., \& Yang, M. (2017). Mechanisms of antifungal and anti-aflatoxigenic properties of essential oil derived from turmeric (Curcuma longa L.) on Aspergillus flavus. Food Chemistry, 220, 1-8. https://doi.org/10.1016/J. FOODCHEM.2016.09.179.

Inmanee, P., Kamonpatana, P., \& Pirak, T. (2019). Ohmic heating effects on Listeria monocytogenes inactivation, and chemical, physical, and sensory characteristic alterations for vacuum packaged sausage during post pasteurization. Lwt, 108(March), 183-189. https://doi.org/10.1016/j.lwt.2019.03.027.

Jesus, M. S., Genisheva, Z., Romaní, A., Pereira, R. N., Teixeira, J. A., \& Domingues, L. (2019). Bioactive compounds recovery optimization from vine pruning residues using conventional heating and microwave-assisted extraction methods. Retrieved from Industrial Crops and Products, 132, 99-110. https://www.sciencedirect.com/science/ article/pii/S0926669019300913?dgcid = coauthor.

Jesus, M. S., Romaní, A., Genisheva, Z., Teixeira, J. A., \& Domingues, L. (2017). Integral valorization of vine pruning residue by sequential autohydrolysis stages. Journal of Cleaner Production, 168, 74-86. https://doi.org/10.1016/j.jclepro.2017.08.230.

Ju, Y., Zhang, A., Fang, Y., Liu, M., Zhao, X., Wang, H., \& Zhang, Z. (2016). Phenolic compounds and antioxidant activities of grape canes extracts from vineyards. Spanish Journal of Agricultural Research, 14. https://doi.org/10.5424/sjar/2016143-8951.

Kamaraj, S., Anandakumar, P., Jagan, S., Ramakrishnan, G., Periyasamy, P., Asokkumar, S., ... Devaki, T. (2019). Hesperidin inhibits cell proliferation and induces mitochondrial-mediated apoptosis in human lung cancer cells through down regulation of $\beta$-catenin/c-myc. Biocatalysis and Agricultural Biotechnology, 18, 101065. https:// doi.org/10.1016/J.BCAB.2019.101065.

Khan, M. K., Ahmad, K., Hassan, S., Imran, M., Ahmad, N., \& Xu, C. (2018). Effect of novel technologies on polyphenols during food processing. Innovative Food Science \& Emerging Technologies, 45, 361-381. https://doi.org/10.1016/J.IFSET.2017.12.006.

Kulshrestha, S. A., \& Sastry, S. K. (2010). Changes in permeability of moderate electric field (MEF) treated vegetable tissue over time. Innovative Food Science and Emerging 
Technologies, 11, 78-83. https://doi.org/10.1016/J.IFSET.2009.10.001.

Kumar, A., Kujur, A., Singh, P. P., \& Prakash, B. (2019). Nanoencapsulated plant-based bioactive formulation against food-borne molds and aflatoxin B1 contamination: Preparation, characterization and stability evaluation in the food system. Food Chemistry, 287, 139-150. https://doi.org/10.1016/J.FOODCHEM.2019.02.045.

Lebovka, N. I., Shynkaryk, N. V., \& Vorobiev, E. (2007). Pulsed electric field enhanced drying of potato tissue. Journal of Food Engineering, 78, 606-613. https://doi.org/10 1016/j.jfoodeng.2005.10.032.

Lima, C. F., Pereira-Wilson, C., \& Rattan, S. I. S. (2011). Curcumin induces heme oxygenase-1 in normal human skin fibroblasts through redox signaling: Relevance for anti-aging intervention. Molecular Nutrition \& Food Research, 55(3), 430-442. https:// doi.org/10.1002/mnfr.201000221.

Liu, P., Wang, W., Tang, J., Bowater, R. P., \& Bao, Y. (2019). Antioxidant effects of sulforaphane in human HepG2 cells and immortalised hepatocytes. Food and Chemical Toxicology, 128, 129-136. https://doi.org/10.1016/J.FCT.2019.03.050.

Loypimai, P., Moonggarm, A., \& Chottanom, P. (2009). Australian journal of basic and applied sciences. Australian Journal of Basic and Applied Sciences. INSinet Publications Retrieved from https://www.cabdirect.org/cabdirect/abstract/20103359466.

Luo, W., Zhao, M., Yang, B., Ren, J., Shen, G., \& Rao, G. (2011). Antioxidant and antiproliferative capacities of phenolics purified from Phyllanthus emblica L. fruit. Food Chemistry, 126(1), 277-282. https://doi.org/10.1016/J.FOODCHEM.2010.11.018.

Luque-Rodríguez, J. M., Pérez-Juan, P., \& de Castro, L. (2006). Extraction of Polyphenols from Vine Shoots of Vitis vinifera by Superheated Ethanol - Water Mixtures. Journal of Agricultural and Food Chemistry, 54(23), 8775-8781. https://doi.org/10.1021 jf061855j.

Mahmoudi, S., Ghorbani, M., Sabzichi, M., Ramezani, F., Hamishehkar, H., \& Samadi, N. (2019). Targeted hyaluronic acid-based lipid nanoparticle for apigenin delivery to induce Nrf2-dependent apoptosis in lung cancer cells. Journal of Drug Delivery Science and Technology, 49, 268-276. https://doi.org/10.1016/J.JDDST.2018.11.013.

Makroo, H. A. A., Prabhakar, P. K., Rastogi, N. K. K., \& Srivastava, B. (2019). Characterization of mango puree based on total soluble solids and acid content: Effect on physico-chemical, rheological, thermal and ohmic heating behavior. $L w t$, 103(September 2018), 316-324. https://doi.org/10.1016/j.lwt.2019.01.003.

Max, B., Salgado, J. M., Cortés, S., \& Domínguez, J. M. (2010). Extraction of phenolic acids by alkaline hydrolysis from the solid residue obtained after prehydrolysis of trimming vine shoots. Journal of Agricultural and Food Chemistry, 58(3), 1909-1917. https://doi.org/10.1021/jf903441d.

Meneses, N. G. T., Martins, S., Teixeira, J. A., \& Mussatto, S. I. (2013). Influence of extraction solvents on the recovery of antioxidant phenolic compounds from brewer's spent grains. Separation and Purification Technology, 108, 152-158. https://doi.org/ 10.1016/j.seppur.2013.02.015.

Moreira, M. M., Barroso, M. F., Porto, J. V., Ramalhosa, M. J., Švarc-Gajić, J., Estevinho, L., ... Delerue-Matos, C. (2018). Potential of Portuguese vine shoot wastes as natural resources of bioactive compounds. Science of The Total Environment, 634, 831-842. https://doi.org/10.1016/J.SCITOTENV.2018.04.035.

Paredes-Gonzalez, X., Fuentes, F., Jeffery, S., Saw, C.-L.-L., Shu, L., Su, Z.-Y., \& Kong, A.N.-T. (2015). Induction of NRF2-mediated gene expression by dietary phytochemical flavones apigenin and luteolin. Biopharmaceutics \& Drug Disposition, 36(7), 440-451. https://doi.org/10.1002/bdd.1956.

Pereira, R. N., Souza, B. W. S., Cerqueira, M. A., Teixeira, J. A., Nio, A., \& Vicente, A. (2010). Effects of electric fields on protein unfolding and aggregation: influence on edible films formation. Biomacromolecules, 11, 2912-2918. https://doi.org/10.1021/ bm100681a.

Pereira, R. N., Teixeira, J. A., Vicente, A. A., Cappato, L. P., da Silva Ferreira, M. V., da Silva Rocha, R., \& da Cruz, A. G. (2018). Ohmic heating for the dairy industry: A potential technology to develop probiotic dairy foods in association with modifications of whey protein structure. Current Opinion in Food Science, 22, 95-101. https:// doi.org/10.1016/j.cofs.2018.01.014.

Pintać, D., Majkić, T., Torović, L., Orčić, D., Beara, I., Simin, N., ... Lesjak, M. (2018). Solvent selection for efficient extraction of bioactive compounds from grape pomace. Industrial Crops and Products, 111, 379-390. https://doi.org/10.1016/J.INDCROP. 2017.10.038.

Rajha, H. N., Boussetta, N., Louka, N., Maroun, R. G., \& Vorobiev, E. (2014). A comparative study of physical pretreatments for the extraction of polyphenols and proteins from vine shoots. Food Research International, 65, 462-468. https://doi.org/10. 1016/J.FOODRES.2014.04.024.

Rajha, H. N., Boussetta, N., Louka, N., Maroun, R. G., \& Vorobiev, E. (2015a). Effect of alternative physical pretreatments (pulsed electric field, high voltage electrical discharges and ultrasound) on the dead-end ultrafiltration of vine-shoot extracts. Separation and Purification Technology, 146, 243-251. https://doi.org/10.1016/J. SEPPUR.2015.03.058.

Rajha, H. N., Boussetta, N., Louka, N., Maroun, R. G., \& Vorobiev, E. (2015b). Electrical, mechanical, and chemical effects of high-voltage electrical discharges on the polyphenol extraction from vine shoots. Innovative Food Science \& Emerging Technologies, 31, 60-66. https://doi.org/10.1016/j.ifset.2015.07.006.

Rajha, H. N., El Kantar, S., Afif, C., Boussetta, N., Louka, N., Maroun, R. G., \& Vorobiev, E. (2018). Selective multistage extraction process of biomolecules from vine shoots by a combination of biological, chemical, and physical treatments. Comptes Rendus Chimie, 21(6), 581-589. https://doi.org/10.1016/J.CRCI.2018.02.013.

Ramadan, E. M., Abou-Taleb, K. A., Galal, G. F., \& Abdel-Hamid, N. S. (2017). Antibacterial, antibiofilm and antitumor activities of grape and mulberry leaves ethanolic extracts towards bacterial clinical strains. Annals of Agricultural Sciences, 62(2), 151-159. https://doi.org/10.1016/J.AOAS.2017.11.002.

Ramírez-Jiménez, A. K., Rangel-Hernández, J., Morales-Sánchez, E., Loarca-Piña, G., Gaytán-Martínez, M., Pereira, R. N., ... Salinas, M. R. (2019). Changes on the phytochemicals profile of instant corn flours obtained by traditional nixtamalization and ohmic heating process. Food Chemistry, 276(December 2018), 57-62. https://doi.org/ 10.1016/J.FOODCHEM.2018.09.166.

Rauf, A., Imran, M., Khan, I. A., ur-Rehman, M., Gilani, S. A., Mehmood, Z., \& Mubarak, M. S. (2018). Anticancer potential of quercetin: A comprehensive review. Phytotherapy Research, 32(11), 2109-2130. https://doi.org/10.1002/ptr.6155.

Rodrigues, R. M., Vicente, A. A., Petersen, S. B., \& Pereira, R. N. (2019). Electric field effects on $\beta$-lactoglobulin thermal unfolding as a function of $\mathrm{pH}$ - Impact on protein functionality. Innovative Food Science \& Emerging Technologies, 52, 1-7. https://doi. org/10.1016/j.ifset.2018.11.010.

Roohbakhsh, A., Parhiz, H., Soltani, F., Rezaee, R., \& Iranshahi, M. (2015). Molecular mechanisms behind the biological effects of hesperidin and hesperetin for the prevention of cancer and cardiovascular diseases. Life Sciences, 124, 64-74. https://doi. org/10.1016/J.LFS.2014.12.030.

Sáez, V., Pastene, E., Vergara, C., Mardones, C., Hermosín-Gutiérrez, I., Gómez-Alonso, S., ... von Baer, D. (2018). Oligostilbenoids in Vitis vinifera L. Pinot Noir grape cane extract: Isolation, characterization, in vitro antioxidant capacity and anti-proliferative effect on cancer cells. Food Chemistry, 265, 101-110. https://doi.org/10. 1016/J.FOODCHEM.2018.05.050.

Sánchez-Gómez, R., Garde-Cerdán, T., Zalacain, A., Garcia, R., Cabrita, M. J., \& Salinas, M. R. (2016). Vine-shoot waste aqueous extract applied as foliar fertilizer to grapevines: Effect on amino acids and fermentative volatile content. Food Chemistry, 197, 132-140. https://doi.org/10.1016/J.FOODCHEM.2015.10.034.

Sánchez-Gómez, R., Sánchez-Vioque, R., Santana-Méridas, O., Martín-Bejerano, M., Alonso, G. L. L., Salinas, M. R. R., \& Zalacain, A. (2017). A potential use of vine-shoot wastes: The antioxidant, antifeedant and phytotoxic activities of their aqueous extracts. Industrial Crops and Products, 97, 120-127. https://doi.org/10.1016/j.indcrop. 2016.12.009.

Sánchez-Gómez, R., Zalacain, A., Alonso, G. L., \& Salinas, M. R. (2016). Effect of toasting on non-volatile and volatile vine-shoots low molecular weight phenolic compounds. Food Chemistry, 204, 499-505. https://doi.org/10.1016/J.FOODCHEM.2016.02.137. Sánchez-Gómez, R., Zalacain, A., Pardo, F., Alonso, G. L., \& Salinas, M. R. (2017). Moscatel vine-shoot extracts as a grapevine biostimulant to enhance wine quality. Food Research International, 98, 40-49. https://doi.org/10.1016/J.FOODRES.2017. 01.004.

Sánchez-Gómez, R., Zalacain, A., Alonso, G. L., \& Salinas, M. R. (2014). Vine-shoot waste aqueous extracts for re-use in agriculture obtained by different extraction techniques: Phenolic, volatile, and mineral compounds. Journal of Agricultural and Food Chemistry, 62(45), 10861-10872. https://doi.org/10.1021/jf503929v.

Tartaglione, L., Gambuti, A., De Cicco, P., Ercolano, G., Ianaro, A., Taglialatela-Scafati, O., ... Forino, M. (2018). NMR-based phytochemical analysis of Vitis vinifera cv Falanghina leaves. Characterization of a previously undescribed biflavonoid with antiproliferative activity. Fitoterapia, 125, 13-17. https://doi.org/10.1016/J.FITOTE 2017.12.009.

Tavsan, Z., \& Kayali, H. A. (2019). Flavonoids showed anticancer effects on the ovarian cancer cells: Involvement of reactive oxygen species, apoptosis, cell cycle and invasion. Biomedicine \& Pharmacotherapy, 116, 109004. https://doi.org/10.1016/J. BIOPHA.2019.109004.

Tourtoglou, C., Nenadis, N., \& Paraskevopoulou, A. (2014). Phenolic composition and radical scavenging activity of commercial Greek white wines from Vitis vinifera L. cv. Malagousia. Journal of Food Composition and Analysis, 33(2), 166-174. https://doi. org/10.1016/J.JFCA.2013.12.009.

Xavier, C. P. R., Lima, C. F., Preto, A., Seruca, R., Fernandes-Ferreira, M., \& PereiraWilson, C. (2009). Luteolin, quercetin and ursolic acid are potent inhibitors of proliferation and inducers of apoptosis in both KRAS and BRAF mutated human colorectal cancer cells. Cancer Letters, 281(2), 162-170. https://doi.org/10.1016/j.canlet. 2009.02.041.

Xavier, C. P. R., Lima, C. F., Rohde, M., \& Pereira-Wilson, C. (2011). Quercetin enhances 5-fluorouracil-induced apoptosis in MSI colorectal cancer cells through p53 modulation. Cancer Chemotherapy and Pharmacology, 68(6), 1449-1457. https://doi.org/ 10.1007/s00280-011-1641-9.

Yang, S., Zhou, J., Li, D., Shang, C., Peng, L., \& Pan, S. (2017). The structure-antifungal activity relationship of 5,7-dihydroxyflavonoids against Penicillium italicum. Food Chemistry, 224, 26-31. https://doi.org/10.1016/J.FOODCHEM.2016.12.001.

Zhu, Z.-Y., Wang, F., Jia, C.-H., \& Xie, M.-L. (2019). Apigenin-induced HIF-1 $\alpha$ inhibitory effect improves abnormal glucolipid metabolism in AngII/hypoxia-stimulated or HIF1 $\alpha$-overexpressed H9c2 cells. Phytomedicine, 62, 152713. https://doi.org/10.1016/J. PHYMED.2018.10.010. 